\title{
MULTIFACETED DIMENSIONS OF INTEGRATION IN TEACHING ENGLISH FOR NATURAL SCIENCES
}

\author{
Volodymyr Sulym \\ Ivan Franko National University of Lviv, Ukraine \\ suwo@ukr.net
}

\begin{abstract}
The research is aimed at discussing multifaceted dimensions of integration in teaching and learning foreign languages for specific purposes, namely - English for Sciences. The author explored the relevance, necessity, efficiency, and challenges teachers face when teaching students ESP in terms of language and professional content integration. The integrated approach has been viewed as contextualised integration of occupational situations, language and speech activity, involving the necessary speech skills and language habits singled out for each particular situation. The participants of the study were 112 teachers from 6 Ukrainian Universities. Specially designed surveys were used in the experiment. The results demonstrated teachers' positive feedback on questions about the ESP relevance at technical universities. It was found that the course content, educational resources and materials should include that scope of knowledge and skills which will correspond to students' professional as well as communicative needs. It can be achieved by the integration of needs and target occupational situation analysis with the course objectives and its content. With a view of enhancing the integration approach in ESP, the author suggests recommendations to follow for successful implementation of the approach.
\end{abstract}

Keywords: integrated approach; English for specific purposes; English for Sciences; needs analysis; course contents; didactic methods; language skills.

\section{Introduction}

The paper explores the benefits of teaching English for Specific Purposes (ESP) to university students majoring in sciences on the basis of the integrated approach. Despite the variety of approaches undertaken to study the problem, few investigations have focused on teaching English for Natural Sciences (ENS) to university students through the integrated approach, taking into account various levels and aspects of integration in language teaching.

For the purpose of stimulating a self-sufficient competent prospective specialist of a natural profile to meet all the requirements of the Ukrainian as well as the global labour markets in order to fulfil professional functions and fully realise a scientific potential within the world educational space, it is necessary to pay special attention to mastering ESP, namely - competence in ENS.

Although teaching ESP has already been researched from different methodological standpoints, it would be of interest to study the problem of teaching ESP from the point of the integrated approach.

For this reason, we have focused on the theoretical basis of teaching ESP. The study is theoretically framed by Harding's (2007) approaches to providing materials for ESP, Basturkmen's (2006) ground research on ESP and communication studies, as well as the studies in developing an English programme for students of science and technology (Basturkmen, 2010), Parkinson's (2013) multi-disciplinary approach to developments in ESP.

The study examines the methodological background, contents of ESP course, methods and techniques of teaching that should be properly integrated in order to achieve maximum feedback.

A multiperspective analysis of the integrated approach to teaching ESP will provide a better understanding of making this process more effective.

\section{Theoretical background}

Integrated approach: the methodological framework for the study

The concept of the integrated approach to teaching process has been a matter of considerable attention of scientific research in education as well as in applied linguistics throughout the world. Ciolan (2008) defines integration as a phenomenon that "...does not represent a subjective desire or an epistemological fad, but it has an objective foundation derived from the dynamic and complex skills needed to solve a problem in a specific context" (p.38) (translated from the original).Toolan (2008) sets the integrationism as the fundamental issue in language teaching, assuming that people make use of the sign in order to communicate, but at the same time claiming that the latter don't come ready-made and predetermined. He then insists that “...new communicational situations require us to adapt as best we can.... And central to that situated communicative adaptation is creating new signs. ... As a consequence, for integrational linguists, human beings are sign makers and not merely implementers of instructions linked to repertoires of fixed signs." (p.2) 
One of the most extensive definitions of the integrated approach is that of Oxford (2001). As it follows from the definition suggested by Oxford (2001), integrated approach“...exposes English language learners to authentic language and challenges them to interact naturally in the language. Learners rapidly gain a true picture of the richness and complexity of the English language as employed for communication. Moreover, this approach stresses that English...becomes a real means of interaction and sharing among people." (p.5)

The ultimate objective of ESP teaching at the end of the last century was to build skills of producing materials and analysing texts both in speaking and writing (Harding, 2007). The research of Biber (2003) "Variation among university spoken and written registers" was also determinant in this area. The first stage of ESP development focused on the analysis of the language at the level of the sentence, the second stage was based on the discursive and rhetorical analysis. At the same time, Basturkmen (2010) claims that the problems which the students encounter don't result from the lack of knowledge of language system, but from the lack of knowledge of peculiarities of foreign language usage. Therefore, teachers can't meet their needs, focusing learning on the practice of language models which are used in various communicative contexts.

Genre analysis wasn't a new trend in ESP language teaching methods. It developed on the framework of register analysis, i.e. the analysis of grammatical features of professionally-oriented texts, suggested by British scientist Ch. Barber in the 70s of the last century. The premise of register analysis was the analysis of the grammatical structure of a sentence. Parkinson (2013) applied the register analysis while teaching the course of ESP and revealed that a great number of identical grammatical and structural forms, e.g. passive constructions, compound nouns and adjectives, were used in the professional related discourse. (p.159). In her monographic study, presenting the findings of register analysis, Mykytenko (2011) asserts that usage of Present Simple, Passive Voice and compound nouns are pertinent to the scientific style of the English language. Register analysis hasn't detected any forms that aren't taught in General English. However, the emphasis shifted towards the process of combining sentences in discourse with the aim to express certain meaning. The researches were performed to define organisational models and linguistic means of expressing those models in texts. Studying those models should be a core of ESP course (Mykytenko, 2011, p.121). Cortes (2004) and Hyland (2008) prove that scientific texts possess lexical bundles which can be characterised as discipline specific. With respect to genre analysis of Sciences, chemistry is characterised by the usage of experiment reports (Parkinson, 2013, pp.162-163).

Typical learning material, compiled according to discursive approach, is designed to teach students to identify text models and discursive markers by means of analysis of texts which contain a great number of above-mentioned models and markers doing "text-diagram" exercises (Harding, 2007, p.25).

From the integrated perspective, ESP teachers are to integrate the professional content with the target language successfully combining certain lexical units, namely terms and grammar structures into language models.

According to Aljiffri (2010), integrated language learning (as well as ESP learning) should be developed at the level of whole language development and all skills integration as well as at the level of interdisciplinary content-based instruction (p.28).

Based on the analysis of the mentioned above sources, we believe that integrated approach to ESP teaching should be viewed as contextualised integration of occupational signs and situations, language and speech activity, involving the necessary speech skills and language habits singled out for each particular situation carefully selected during the observation of occupational activity of professionals in the area of Natural Sciences.

\section{Methods}

The methods of analysis and synthesis have been used in the first (theoretical) part of the study followed by pedagogical experiment with 112 teachers of Ukrainian universities (Ivan Franko National University of Lviv - LNU, Volodymyr Hnatiuk National Pedagogical University of Ternopil - TNPU, Mukachevo State University - MSU, Vinnytsia Mykhailo Kotsiubynski State Pedagogical University - VSU) together with analysis and interpretation of its results as the main research method of the second (empirical) part of the study. Specially designed surveys were used in the experiment.

The questions under research were as follows: 1) Do teachers consider that English can be taught in the same way for Basic Sciences (Mathematics, Physics, Geography, Biology, Chemistry, Information Technologies, Economics) or there are considerable differences in the content and methodology of teaching leading to specific attention on the part of the teacher? 2) Can Integrated Approach be considered as the most effective in solving the problems with teaching English for specific needs of the students of Sciences in each particular subject area? 


\section{Results}

To prove the efficiency and applicability of the mentioned above assumptions, an empirical study was carried out among 112 teachers of English at four educational establishments of western and central Ukraine. The results of the data suggest that a vast majority of teachers (average $86 \%$ of the respondents, see the first two columns) are totally convinced that each area of Sciences demands specific attention on the part of the teacher in designing the contextualised content, resources and materials, as well as applying specific teaching methods related to getting students prepared to use English in their future occupational activity (fig. 1).

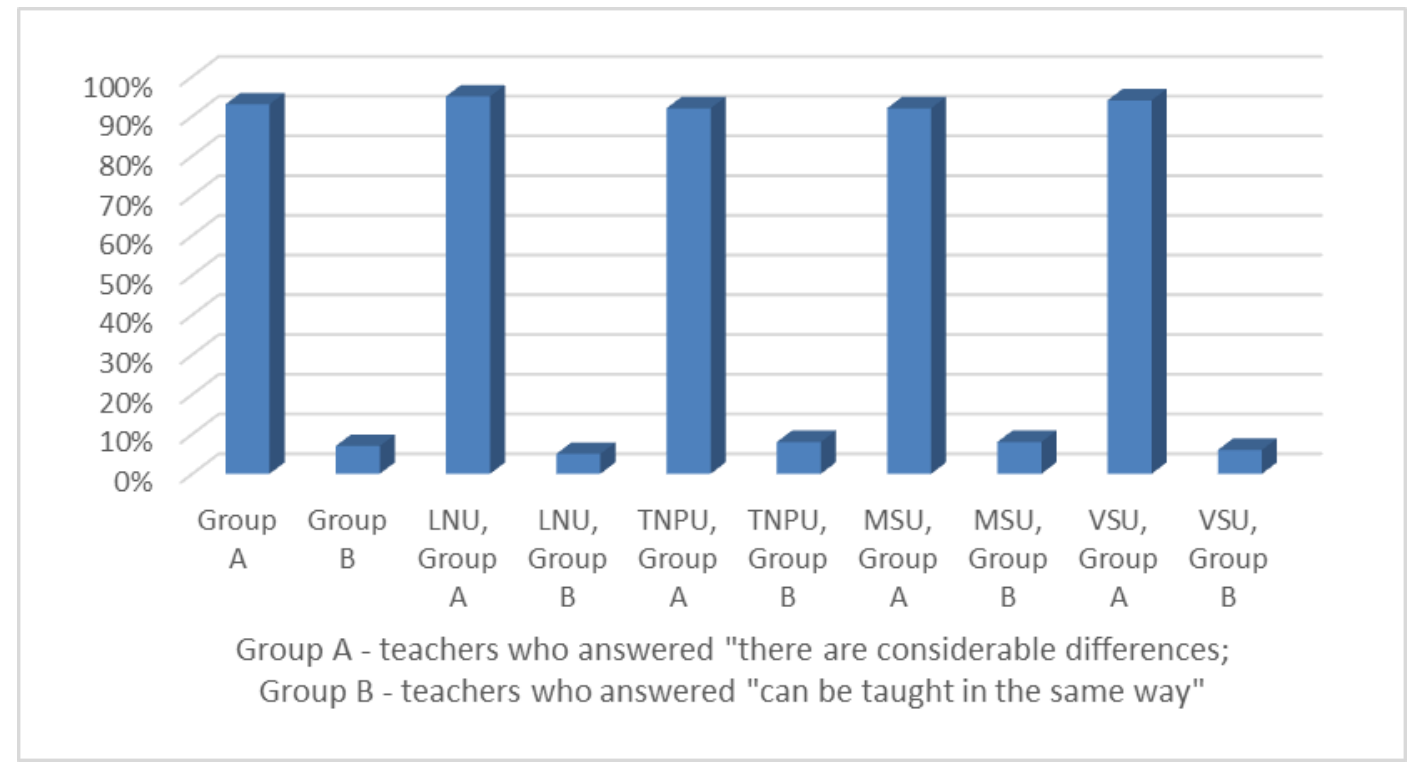

Figure 1. The results of the empirical study concerning research question 1.

In a similar vein, $93 \%$ of teachers believe (see the last two columns in fig. 2 showing the average data) that Integrated Approach should be the first one to consider and followed while designing the resources and materials for teaching English for specific needs of the students of Natural Sciences (fig. 2).

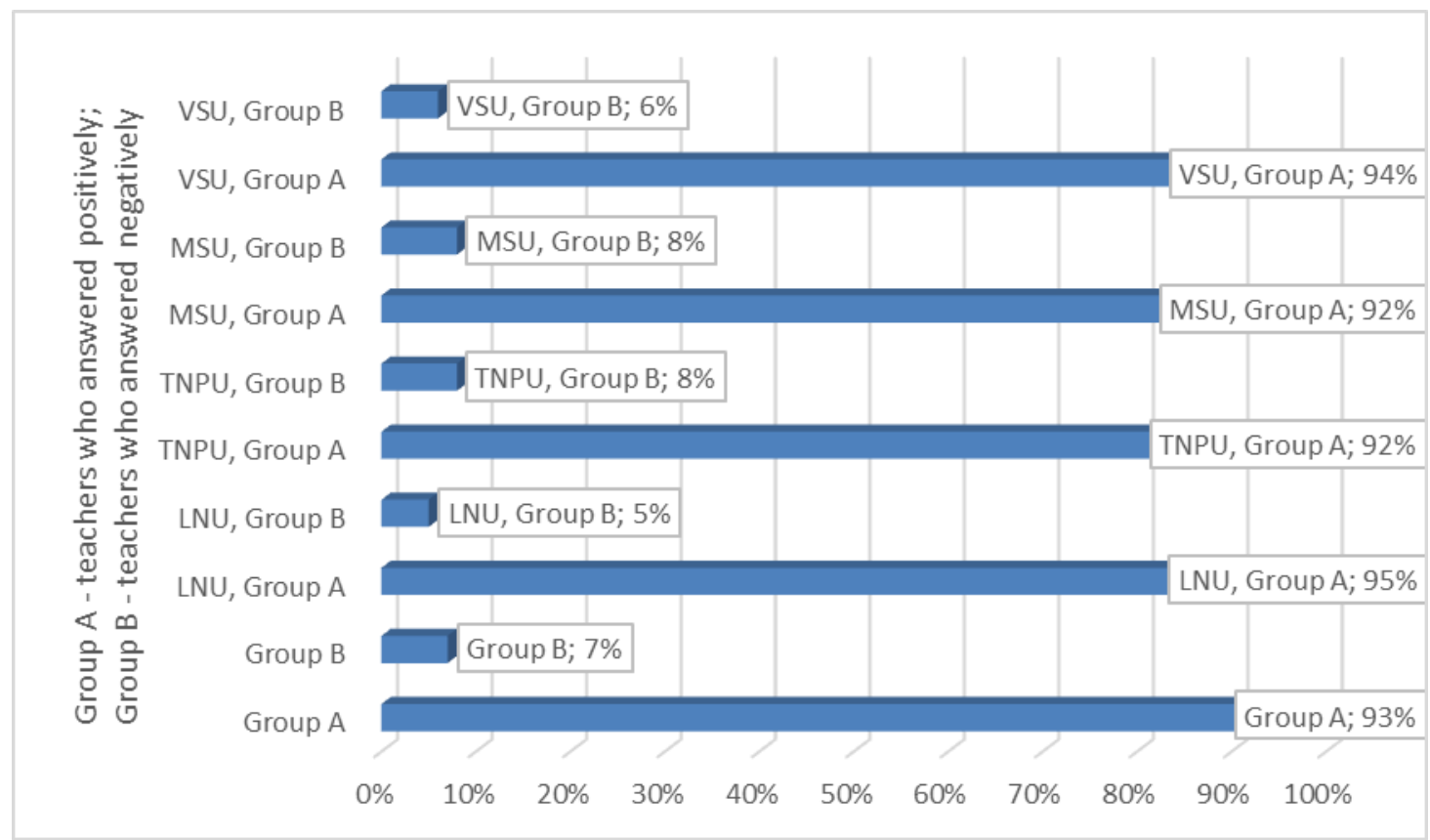

Figure 2. The results of the empirical study concerning research question 2.

\section{Discussion}

Integration of needs and target situation analysis with the course objectives and its contents

The process of outlining the objective of the course is closely bound with the analysis of students' needs and target situation. The term "analysis of a target situation" was offered by Chambers (2005). Harding 
(2007) accomplished further study of target situation analysis (pp. 24-40). She elaborated the system of learners' needs and represented it in the model which comprised communicative goals, tasks and means of communication, language skills, functions, structures. Analysis of a target situation allowed arranging students' needs that are to be centred in the process of developing the contents of learning subject.

One of the important scientific requirements to the contents of the course of ENS, its updating and improvement is the disclosure of the relationship between subjects of study, namely professional courses and ESP course (Morska, 2018, p. 86). In the process of acquiring professionally significant knowledge, the integration of personal experience and professionally significant disciplines contributes to developing students' professional competence and humanitarian as well as social disciplines develop their soft skills. (Kharlamov, 2004).

Taking into consideration students career needs, we cannot omit the issue of soft skills acquisition which takes place at ESP classes. It will prepare students to cope with future professional challenges. Lavrysh (2016) determined the list of soft skills which can be successfully developed at ESP classes: skills of oral and written communication, listening skills, critical thinking, decision-making, problem-solving, presentation skills, teamwork and leadership, cultural awareness, negotiating skills, self-organisation and self-control skills. Thus, ESP learning outcomes should be focused on students' personal growth and employability skills development. In order to equip students with soft skills, and meet the demands of employers for qualified staff, it is important to provide high-quality and diversified ESP teaching .

It is essential for the contents of ESP course to be developed not only methodically but also systematically, as a logically designed system of professional knowledge, not as a set of scattered fragments of knowledge (Tarnopolsky, 2010). Moreover, the problem of discrepancy of the terms of learning ESP by students of Sciences arises. According to many syllabuses, ESP is taught in 2-3 (4) semesters while subjects of professional cycle are taught only in 5 semester. Thus, the contents of ESP course in the process of training Bachelors, Masters of Sciences and Doctors of Philosophy/Candidates of Sciences in the majority of Ukrainian higher educational institutions presupposes learning ESP within $2^{\text {nd }}$ and $3^{\text {rd }}$ (sometimes $1^{\text {st }}$ and $4^{\text {th }}$ ) semesters and learning Academic English within 2 semesters while obtaining Master of Sciences and Doctor of Philosophy / Candidate of Sciences degree (Mykytenko, 2011, 101).

\section{Didactic methods of the integrated approach realisation in the course of English for Sciences}

The important component of ESP, namely - ENS teaching is its methodological aspect of implementation. Integrated ties realise best in the process of organisation of learning with the help of the means of untraditional forms and methods such as (Mykytenko, 2011, 115):

- innovative lectures in professionally-oriented subjects conducted in foreign language: problemsolving lectures, mutual lectures (lecture with a foreign language teacher), lectures with deliberate mistakes, visual lectures, lectures-disputes;

- integrated seminars, problem-solution seminars, thematic seminars, systematic seminars;

- didactic games, role-plays, business games.

Parkinson (2013) believes in the strength of methodology and views it in the way in which language learning and subject learning approaches can be integrated.

The didactic methods of the integrated approach realisation of ESP with professionally oriented disciplines in the process of training are the following:

- in the ESP classroom, knowledge and skills are usually acquired in an integrated way while reading a text, preparing a report, speech or presentation which involves at least three or four main language skills, namely reading, writing, speaking and listening. Thus, it is appropriate to apply an integrated skills approach (Parkinson, 2013) while teaching ENS as well;

- study of specific features of academic and scientific styles from authentic professional literature that involves such learning methods as reading, taking notes, translation, compilation of glossaries of terms; professional talks and disputes, dialogues, didactic games: role plays, simulations;

- individual and group projects with professional topics;

- presentations about scientific inventions;

- reports for international scientific conferences targeted at students as well as prominent scientists.

On the basis of the performed analysis we can assume that the ways to improve the effectiveness of the integrated approach realisation in the course of ENS lie in the following:

- adjustment of the contents of syllabuses of foreign language and semester plans with the contents of the courses of social, humanitarian, fundamental and professionally-oriented disciplines by a thematic principle; 
- implementation of didactic principles of system, succession and sequence which require stage-bystage sequence of learning certain courses of study and topics within these courses;

- coordinated work of lecturers of all courses while training Bachelors, Masters, Doctors of Philosophy / Candidates of Science on designing curricula of training prospective specialists;

- internal, inter-institutional, domestic, and international seminars, conferences and congresses.

The integrated approach allows solving the problem of implementation of integrated ties, the problem of a limited amount of learning time for the course of ESP, as well as the problem of motivation of students through bilingual learning as well. Bilingual learning is learning by means of native and foreign language, perfect mastery of which is a component of learning objectives. If the level of ESP competence is introductive, medium or threshold the method of "language gradient" or "immersion" can be applied. This method entails a successive systematic increase of foreign components in the contents of learning. Under the condition of implementation of the integrated approach to vocational training of specialists of Sciences through bilingual learning the effectiveness of building ESP competence increases. It also induces to solve the problem of significant decrease of ESP competence during the period when programmes of training of Bachelors of Sciences don't include learning a course of foreign language or ESP.

One of the forms of integrated study that is based on extension of integrated ties is "learning together", i.e. a certain synthesis of two or more disciplines: language/literature and history, language/literature and sciences. Such forms of organisation of learning are successfully used in some American colleges, i.e. Community College (Holyoke). Though given the name of "integrated", this approach bears some similarities with the interdisciplinary fundamentals.

In ENS classes abilities and skills of speaking should be developed together with the use of authentic learning provision selected for the use in each particular situation of the occupational activity. This strategy contributes to stage-by-stage development of ESP competence.

With the aim to acquire lexical material successfully in the combined English class a lecturer should use various types of lexical units, namely: words and phrases as units of "language content" under the topic of the lesson, language units of "conversational process" and units of "functional language". The examples of "functional language" are the phrases of agreement, disagreement, expressing one's opinions: I think, Come on, Well, it's true.

Implementation of the principles of integrated ties, incorporation of theory into practice, correlation the contents of syllabuses of Bachelors and Masters of Sciences training includes direct assessment and model experiments at the classes on ESP as well. Besides, the method of individual and group projects can also be used that involve independent work on research experiment and presentation and demonstration of the experiment and its findings at the lecture or seminar (Mykytenko, 2011, 122-124).

The research has shown that concentrating on the integrated approach to teaching and learning a foreign language for specific purposes with the aim to develop a high level of ESP competence in prospective specialists of Sciences the following factors should be taken into consideration:

- setting the objectives of academic discipline "Foreign Language for Specific Purposes" on the basis of needs analysis of students majoring in Sciences, analysis of target situation and designing the system of students' needs that comprise communicative goals, tasks and means of communication, language skills, final level of foreign language for specific purposes competence;

- modifying the didactic methods as well as the contents of academic disciplines "Foreign Language" and "Foreign Language for Specific Purposes", increasing significantly the number of learning hours for these disciplines, integrating disciplines of fundamental and professional cycles with English language instruction in the $5^{\text {th }}-8^{\text {th }}$ semesters of Bachelors' training and during the course of Masters of Sciences training;

- building integrated Foreign Language for Specific Purposes learning at the level of all language skills integration, namely - speaking, writing, reading and listening;

- discrepancy between knowledge necessary for comprehension of an academic professional text and knowledge necessary for comprehension of a general text;

- absence of discrepancy between grammatical, functional and discursive systems among professional texts of Sciences;

- specific usage of certain grammatical construction in academic style, i.e. certain grammatical structures that are pertinent to professional texts are to be dominant while learning grammar;

- the use of fewer professional vocabulary items in further professional activity of prospective specialists of Sciences;

- dominance of four types of lexical units of different fields of Sciences: structural, general, sub-field and field vocabulary blocks; 
- necessity to define potential professional situations and analyse linguistic characteristics of these situations.

It should be mentioned that the suggested assumptions have been empirically proved by means of the feedback from ESP teachers working at Ukrainian universities.

Nowadays most Ukrainian higher educational institutions haven't created appropriate conditions for successful implementation of the principles of succession and sequence in the context of the integrated approach concerning foreign language learning. Thus, curricula of professional training of Bachelors of Chemistry, Geology, and Geography at most domestic higher institutions include learning of foreign language in 1-4 semesters.

Let's illustrate allocation of learning time among the courses of learning disciplines that provide theoretical training of prospective Bachelors of Geography, who entered Ivan Franko National University of Lviv in 2014/2015 (Fig. 3).

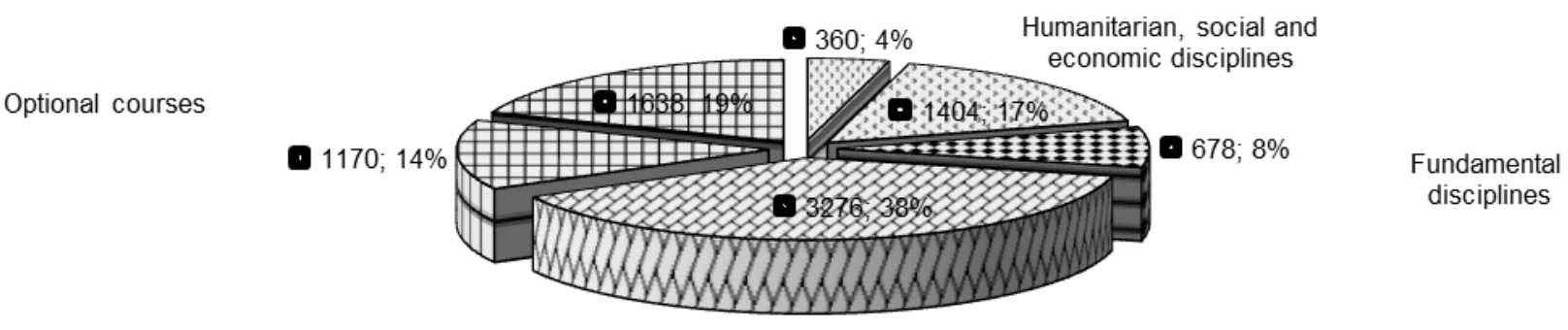

Professional disciplines

Figure 3. Allocation of learning time among the courses of learning disciplines that provide theoretical training of prospective Bachelors of Geography, who entered Ivan Franko National University of Lviv in 2014/2015

The course "Foreign Language" is allotted $360 \mathrm{~h}$ by the curriculum for training the Bachelor of Geography and is a part of the block of humanitarian, social and economic disciplines $(1,764 \mathrm{~h}, 20 \%$ of the whole learning time). $678 \mathrm{~h}$ are allotted for learning fundamental disciplines ( $8 \%$ of the whole learning time). The most amount of learning time - 3276h. (39\%) are provided for learning by prospective Bachelors of Geography professional disciplines. A lot of learning hours - 2808 (33\%) are allotted for optional subjects and 1638h. (19\%) are given for the subjects which students choose on their own that testifies an adherence to the principles of individualisation and professionalisation of training.

In most Ukrainian higher educational institutions most syllabuses of foreign languages it is claimed that during the $3-4^{\text {th }}$ semesters students should work up professional topics whereas a study of professional disciplines is planned to be introduced only in the 4th-8th semesters. In the $5^{\text {th }}-8^{\text {th }}$ semesters learning of foreign language isn't planned. During this period student are gradually losing the developed ESP competence. Entering Master's courses, graduates take an exam in English. While doing their Master's studies, they continue learning the course ESP, namely - ENS. According to the requirements of syllabuses, students are to possess a high level of ESP competence from the beginning of the course (Mykytenko, 2011, 101).

At some higher educational institutions like Ivan Franko National University of Lviv in the Master's programme the integrated approach is incorporated in the following way. Masters of Sciences while writing their master's papers are supposed to work up about 50 foreign sources, make a summary of a diploma paper, compile term glossary that lists more than 200 units. The defence of diploma papers at student's will is conducted both in Ukrainian and foreign language (English or German). Therefore, Masters should have a high command of ESP competence.

For that reason, academic disciplines "Foreign Language" and "ESP" should be closely bound with the blocks of fundamental and professional disciplines. A foreign language teacher should present not only lexical and grammatical material but also familiarise students with target culture, etiquette, help student get about in the basics of professional disciplines, implementing in this way the principle of integrated ties.

Though Harding (2007) assumes that the approach to ESP learning can be common for different fields of Sciences and there aren't grammatical, functional or discursive structures of professional texts that are pertinent to Biology, Physics or Geography, the differences of the fields lie in lexical (term) layer and density of certain grammatical and structural forms.

We outline four types of lexical units of a certain field that a teacher should focus on in the process of learning FSP.

- $\quad$ structural vocabulary: auxiliary verbs, pronouns, infinitive, gerund, conditionals; 
- general vocabulary (e.g. for Geography - weather, forecast, cause etc.)

- subfield vocabulary (e.g. for Geography - spring, acid)

- field vocabulary (e.g. for Biology - auricle, chromosome).

Communicating in English in further professional activity, prospective specialists use less field vocabulary than general one. While learning ESP field vocabulary makes up 9\% out of the whole lexical learning material.

Kramsh (2004) says that the contents of learning English should include a standard linguistic system and frequent used variants as well (p.11). A teacher should pay attention to the facts and relations between ties. It makes the experience of students versatile and induces the reflection of diversity.

Basturkmen (2006) proves that linguistic knowledge, necessary for comprehension of specialised texts, differs from linguistic knowledge for comprehension of general text. General comprehension depends on the knowledge of a subject, but not on the knowledge of language. Basturkmen (2006) claims that ESP isn't distinguished by the quantity of terms in text, but by factual knowledge, necessary to understand these terms. The usage of authentic texts gives the student an opportunity to feel "natural" usage of a foreign language, motivates them to study, and facilitates to build communicative skills (Basturkmen, 2010). Different types of professional texts are used at different stages of learning ESP depending on the learning objectives. The most widespread texts are texts, adapted to the target situation; texts that stimulate certain activity; texts that illustrate certain discursive models (Mykytenko, 2011, pp.99-104). The scientists agree that authentic texts or texts that are given authentic shape much more motivate students to study and stress that importance of the text doesn't come down to the text, but to the role which the text pays in learning (Parkinson, 2013, pp.157158). The assumption implies that while designing the course of ESP, choosing methods of teaching, preparing teaching and methodical provision it is necessary to choose the texts which comply most with objectives and aims of the course.

\section{Conclusions}

Giving a comprehensive evaluation of studied materials, we want to highlight the importance of adherence to the main principles of integration that are too typical for the contents of the professional training system for a prospective specialist of Sciences. The principles are: principle of realisation of integrated ties, succession and sequence in presentation of learning material, flexibility and variance of syllabuses, application of theory in practical training, orientation to further practical activity of prospective specialists and consideration of needs of labour market, adherence to the principles of individualisation and specialisation owing to the balance between compulsory and elective disciplines.

A great number of teachers participated in the survey admitted that the integration approached influenced the students' attitude toward language learning and enhanced the motivation due to the introduction of authentic professional content into language learning. Students have an opportunity to employ their acquired professional theoretical knowledge into the practice while performing communicative interactive tasks and activities such as simulations, projects and case studies.

\section{References:}

Aljiffri, I. (2010). Effects of the Integrated Approach to Teaching English and Social Studies on Achievement in a Saudi Private Elementary School. Journal of Educational \& Psychological Sciences, 11 (3), 11-31.

Biber, D. (2003). Variation among university spoken and written registers: A new multi-dimensional analysis. In Ch.Meyer \& P. Leistyna (Eds.), Corpus Analysis: Language structure and language use (pp.47-70). New York, NY: Rodopi. https://doi.org/10.1163/9789004334410_005

Basturkmen, H. (2006). Ideas and Options in English for Specific Purposes. Mahwah, New Jersey: Lawrence Erlbaum Associates, Inc.

Basturkmen, H. (2010). Developing Courses in English for Specific Purposes. New York: Palgrave Macmillan. https://doi.org/10.1057/9780230290518

Byram, M. \& Brumfit, Ch. (Eds.) (2002). Encyclopedia of Language Teaching and Learning. London: Routledge. https://doi.org/10.4324/9780203219300

Chambers, A. (2005). Integrating corpus consultation in language studies. Language Learning \& Technology, 9(2), 111-125.

Ciolan, L. (2008). Învăţarea Integrată: fundamente pentruun curriculum transdisciplinar. Polirom.

Cortes, V. (2004). Lexical bundles in published and student disciplinary writing: Examples from history and biology. English for Specific Purposes, 23(4), 397-423. https://doi.org/10.1016/j.esp.2003.12.001

Harding, K. (2007). English for Specific Purposes. Oxford: Oxford University Press.

Hyland, K. (2008). As can be seen: Lexical bundles and disciplinary variation. English for Specific Purposes, 27(1), 4-21. https://doi.org/10.1016/j.esp.2007.06.001

Kharlamov, I. (2004).Pedagogics. Minsk: Higher School.

Kramsch, C. (2004). Context and Culture in Language Teaching. Oxford Applied Linguistics. Oxford: Oxford University Press.

Lavrysh, Yu. (2016). Soft skills acquisition through ESP classes at technical universities. Journal of teaching English for specific and academic purposes, 4 (3), 517-525. https://doi.org/ 10.22190/JTESAP1603517L

Morska, L., Horpinich, T., \& Olendr, T. (2018). Teaching Medical Students' Professional English Reading on the Basis of Individual Cognitive Learning Styles. Science and Educatin, 2, 86-93. https://doi.org/10.24195/2414-4665-2018-2-11 
Mykytenko, N. (2011). Tekhnolohiya Formuvannia Inshomovnoyi Profesijnoyi Kompetentnosti Majbutnikh Fakhivtsiv Pryrodnychoho Profiliu [Technology of the Development of Foreign Language Professional Competence of Future Specialists in Natural Sciences]. Ternopil, Ukraine: TNPU.

Nguyen, H., Nguyen, T. (2017). ESP: Perceptions of students and teachers of learning needs at Vietnamese schools. Int. J. of Adv. Res, 5 (4), 793-803 (ISSN 2320-5407). http://dx.doi.org/10.21474/IJAR01/3877

Oxford, R. (2001). Integrated skills in the ESL/EFL Classroom. ERIC Digest. Retrieved 15 July 2018 from https://files.eric.ed.gov/fulltext/ED456670.pdf

Parkinson, J. (2013). English for Science and Technology. In B. Paltridge \& S. Starfield (Eds), The Handbook of English for Specific Purposes. Oxford: Wiley-Blackwell.

Sarré, C. \& Whyte, S. (2017). New developments in ESP teaching and learning research. Voilans, France: Research-publishing.net. https://doi.org/10.14705/rpnet.2017.cssw2017.9782490057016

Starfield, S. (2014). Current and Future Directions in English for Specific Purposes Research. Revue française de linguistique appliquée, XIX (1), 9-14. Retrieved 15 July, 2018 from https://www.cairn.info/revue-revue-francaise-de-linguistiqueappliquee-2014-1-page-9.htm.

Tarnopolsky, O. (2010). Konstruktivistskaya metodika smeshannogo obucheniya angliyskomu yazyiku dlya spetsialnyih tseley v nefilologicheskih vyisshih uchebnyih zavedeniyah [Constructivism methods of mixed learning of ESP in non-linguistic higher educational institutions]. Bulletin of Lviv State University of Life Safety, 4, 224-229.

Toolan, M. (Ed.) (2008). Language Teaching: Integrational Linguistic Approaches. New York: Routledge. https://doi.org/10.1017/s0047404511000340 